Acta Protozool. (2017) 56: 109-118

www.ejournals.eu/Acta-Protozoologica

doi:10.4467/16890027AP.17.009.7484

PROTOZOOLOGICA

\title{
Improvement of Silver Impregnation Technique Using in Situ Synthesized Protargol
}

\author{
Alexander V. KURILOV \\ Institute of Marine Biology NAS of Ukraine, Odessa, Ukraine
}

\begin{abstract}
An improved impregnation method for ciliates has been described with a new formulation for silver proteinate synthesized in situ, that avoids necessary its long-time laboratory synthesis or use of expensive commercial protargol. Compared to conventional techniques, the proposed protocol is more time-saving, reduces the consumption of chemicals and excludes some hazardous ones (e.g. xylene). Structures that are impregnated such as nuclear apparatus, infraciliature, cortical and cytoplasmic microtubules are stained almost identical compared to other protargol methods. Advantages of this method allow us to merge it successfully with ecological quantitative studies of various natural communities of ciliates and provide correct identification of species during such investigations.
\end{abstract}

Key words: ciliates, in situ synthesized protargol technique, staining method

\section{INTRODUCTION}

Silver impregnation of ciliates is a basic indispensable technique for their morphological identification (Dieckmann 1995, Ma et al. 2003). In quantitative investigations of ciliate populations and communities from different natural habitats, the correct identification of species allows assessing the species diversity and environmental status of water bodies based on these data. The complexity of such studies is that both, a standard quantitative accounting procedure ("live counting" technique, inverted microscopy) and species identification procedure using impregnation techniques, are difficult, time and cost consuming, and required serious

Address for correspondence: Alexander Kurilov, Institute of Marine Biology NAS of Ukraine, Pushkinskaya str., 37, Odessa 65011, Ukraine; Tel./fax: +380 4872509 18; E-mail: akur@ukr.net skills. This limits considerably the number of samples that can be taken and processed. For this reason, ecological investigations are often restricted to size-classes or even communities whereas species composition and distribution are still not well researched (Petz 1999).

Partially, this problem has been solved by developing of QPS method and its modifications (Montagnes and Lynn 1987, Skibbe 1994). However, these techniques are quite laborious, and sometimes yield the unpredictable result with possible loss of the entire material. Silver carbonate methods, designed for freshwater and marine species (Fernandez-Galiano 1976, 1994; Foissner 2014; Ma et al 2003) necessarily require living material only. Moreover, the trials and errors method must be frequently used to obtain the best results, because an impregnation quality depends on a number of unforeseen factors, for example, some species of ciliates are poorly fixed in formol. The simple "dry silver nitrate" method (Klein 1958, Foissner 2014) is 
inappropriate for marine species due to undesirable precipitation of silver chloride.

Nevertheless, numerous modifications of protargol impregnation techniques (except QPS), which are used primarily for qualitative studies, represent a rich material for analyzing and can be combined with quantitative studies. All these techniques have several standard steps: fixation, mounting, bleaching, impregnation, development with the following fixing, and mounting of permanent slides. The existing modifications usually relate to one or more of these steps and have been analyzed in detail (Diekmann 1995, Silva-Neto 2000, Foissner 2014).

More than 20 years of personal experience of developing the best combination of quantitative and qualitative studies, enabled to improve the procedure of impregnation, which has been successfully used for the last five years in a quantitative research of ciliate communities from various freshwater, marine and hypersaline habitats in the benthos, plankton and fouling.

The method of silver impregnation described in this paper is a modification of methods from several sources (Tuffrau 1967, Lynn 1992, Wicklow and Hill 1992, Diekmann 1995, Silva-Neto 2000, Foissner 2014). The main innovation is the use of silver proteinate obtained in situ from silver nitrate, peptone and sodium hydroxide. Also, some stages have been reduced or completely eliminated.

\section{MATERIALS AND METHODS}

All species of ciliates used in this work were collected from various habitats during quantitative investigations. Freshwater samples were obtained from Danube $\left(45^{\circ} 23^{\prime} 48^{\prime \prime} \mathrm{N}, 29^{\circ} 34^{\prime} 60^{\prime \prime} \mathrm{E}\right.$, plankton and fouling from cane surface). Brackish-water samples $\left(\approx 15 \%\right.$ ) were collected in the Black Sea $\left(46^{\circ} 28^{\prime} 32^{\prime \prime} \mathrm{N}, 30^{\circ} 45^{\prime} 59^{\prime \prime} \mathrm{E}\right.$, plankton, coastal psammon and seaweeds-associated community). Samples from hypersaline habitats $(\geq 180 \%$ ) were collected in Kuyal'nitskiy Liman (46 $34^{\prime} 28^{\prime \prime} \mathrm{N}, 30^{\circ} 45^{\prime} 17^{\prime \prime} \mathrm{E}$, sediments).

Both, native material (unfixed and unconcentrated water samples for "live counting" procedure) and bulk-fixed with concentrated Bouin's fluid (Montagnes and Lynn 1987) samples (for inverted microscopy) were used.

\section{DESCRIPTION OF THE METHOD}

1.1. Bulk-fixed samples processing. Concentrate ciliates by centrifugation (or settling) and then wash them two or three times with distilled water until the yellow colour disappears. Avoid excessive washing, as this may weaken the impregnation. After the last washing, discard supernatant, leaving about $0.1 \mathrm{ml}$ of the sample. Add $0.01 \mathrm{ml}$ of Mayer's albumen-glycerol fluid and mix gently to prevent foaming. Incubate the cells in this solution for about $30 \mathrm{~min}$. Place the droplets with the precipitated ciliates evenly on 2 or 3 grease-free coverslips $(24 \times 24 \mathrm{~mm})$ and distribute across the surface using a mounting eyelash or fine insect needle. Remove excess liquid carefully with a micropipette.

1.2. Native samples processing. While performing the "live counting" procedure under a stereomicroscope, pick out each counted specimen from counting chamber (e.g. Bogorov's counting tray) using a micropipette and place it into embryonic dish half-filled with Buin's fixative. Also, a concave slide or watch glass may be used. NOTE. A "live counting" usually takes a long time due to necessary pre-identification of certain species in vivo under a high magnification of a microscope. To prevent the fixative fluid from drying or crystallizing, cover the embryonic dish with a lid, or hold the concave slide or watch glass in a Petri dish with moist filter paper on the bottom.

Leave ciliates at least $20-30 \mathrm{~min}$ in fixative after the end of counting procedure, or upon reaching a sufficient amount of material (for qualitative studies). Concentrate the cells in the middle of the dish by swirling the liquid with a micropipette and carefully remove the fixative, leaving one as little as possible. Add distilled water and repeat washing 3-4 times up to the disappearance of yellow colour. In the case of a scarce or valuable material, the washing can be carried out by sequential transferring cells by a micropipette from the dish to a new one, filled with fresh distilled water (usually 3-4 times is sufficient for the desired purity). Assemble the cells at the middle of the dish in the last portion of water. Add several drops of diluted (1:10) Mayer's albumen-glycerol fluid from a micropipette over the cells and sustain 2-3 minutes. Pick out the ciliates and inject them into the dish with Mayer's fluid, diluted as described above. NOTE. The ciliates emerge in this solution. Use a micropipette to speed up their immersion. Avoid formation of bubbles!

After settling, carefully collect the cells from the centre of the dish. Transfer the ciliates with the smallest possible volume of liquid onto the middle of a degreased small coverslip $(18 \times 18 \mathrm{~mm})$. Gently remove an excess of a fluid from the drop by a micropipette until the layer of liquid being approximately equal to a half of the thickness of the cells. Large and small specimens can 
be mounted for this purpose on different coverslips. At this step, cells can be separated from one another and oriented as desired using mounting eyelash.

1.3. Dry the coverslips with obtained smears on a hot plate at $50-60^{\circ} \mathrm{C}$ up to albumen film hardening (test it with mounting eyelash). Such coverslips with smears can be stored in a lidded Petri dish with a sachet of silica gel for several weeks or even months until being impregnated.

The following steps are carried out in small Petri dishes $(\varnothing 3.5 \mathrm{~cm})$ and can be easily controlled under a stereomicroscope. The addition of the solutions performed with a pipette by applying them dropwise to the surface of smear until it covered at least $3 \mathrm{~mm}$ layer (it is recommended, otherwise the coverslip may float, or not be covered completely by fluid). For washing smears, the amount of water added should be at least half of the volume of the Petri dish. Also, it is advisable from time to time gently lift the edge of the coverslip by a thin dissection needle to flush out the grout between the bottom of the dish and glass. To remove liquids, it is convenient to use a rubber or silicone pear with a thin (1-2 mm) tip.

2. Fixation of smears. Add alcohol-formaldehyde solution $(4: 1 \mathrm{v} / \mathrm{v}, 4$ parts of $96 \%$ vol. alcohol +1 part of $37 \%$ commercial formaldehyde) and fix for 1-2 min. Remove the liquid and wash two times for 2-3 minutes. This procedure enables to avoid the detachment of albumen layer during the processing of the technique (Tuffrau 1967, Silva-Neto 2000). Moreover, additional fixation makes the cells more rigid and prevents undesirable excessive flattening or distortion of specimens during further mounting of permanent slides (see step 5).

3. Bleaching. In fact, this procedure can be performed just before mounting of the cells (see step 1.2) using sodium hypochlorite. However, here are some known problems with the choice of the appropriate concentration of bleaching reagent (Foissner 2014). Furthermore, ciliates in sodium hypochlorite strongly swell and may burst that along with the further necessary prolonged washing increases the risks of whole material lost. Thus, potassium permanganate bleaching is safer.

Add $0.2 \%$ potassium permanganate solution to the smear. After about 2-3 minutes remove the solution and add distilled water. Repeat rinsing. Add 2-2.5\% oxalic acid solution (exact concentration is not significant) and wait until the disappearance of traces of brown staining of the cells and albumen film (usually, 1-2 minutes is enough). Wash with distilled water 3-4 times for 3 minutes. NOTE. Personal experience has shown that the bleaching time depends not only on the cell size, but also on the content of organic matter in the distilled water used to prepare potassium permanganate solution. Therefore, the bleaching time can vary substantially from 30 seconds up to 3-4 minutes and appropriate time should be chosen individually by trials and errors. In any case, let potassium permanganate solution settle after preparation for at least one day to precipitate flakes of oxidized organic substances that can damage the albumen layer. For the same reason, should be avoided a random shaking of the solution. Do not use filtration to remove the flakes because a filter can bring in a new portion of organic matter.

4. Impregnation. Silver proteinate can be synthesized before steps 2 and 3. It is prepared as follows (based on the simultaneous impregnation of four coverslips): sprinkle $85 \mathrm{mg}$ of powdered peptone on the surface of $8 \mathrm{ml}$ distilled water in a small beaker and let it dissolve without stirring. Add $1 \mathrm{ml}$ of $0.3 \%$ sodium hydroxide solution and, mixing thoroughly with the glass rod, added dropwise $1 \mathrm{ml}$ of a $1.26 \%$ solution of silver nitrate. NOTE. Solutions should be prepared with cold boiled distilled water to prevent the formation of carbonates, the traces of which can adversely affect the impregnation quality. For this reason, it is advisable to store sodium hydroxide solution in the capped 5-10 $\mathrm{ml}$ syringes that have plastic (not rubber!) pistons. Silver nitrate solution must be stored in the dark.

Obtained mixture corresponds to approximately $1 \%$ solution of commercial protargol that contains $8 \%$ of silver based on a dry weight recalculation. Test the $\mathrm{pH}$ of the fluid using universal $\mathrm{pH}$ indicator paper and adjust to $\mathrm{pH}=7.5-8.5$ with $0.3 \%$ sodium hydroxide solution. Actually, to obtain a reliable result, this fluid should be added to $0.5-1.5 \mathrm{ml}$ of sodium hydroxide solution depending on the grade of peptone and its buffer capacity. The concentration of silver in an adjusted mixture only slightly decreases and does not affect the impregnation quality. However, if the $\mathrm{pH}$ remains below 7 , use a more concentrated solution of sodium hydroxide, but in the mentioned above volume range. NOTE. The crucial factor is the $\mathrm{pH}$, which should not exceed the specified values. Do not add copper to the obtained protargol, otherwise, it can completely lose its activity due to the deposition of metallic silver.

The mixture gradually changes colour, becoming at first a little pink, and then reddish-brown. Add silver proteinate mixture to the Petri dish with a smear, cover with a lid and leave for 12-24 hours at room 
temperature, or place this lidded Petri dish (or 2-3 dishes) into a broader one with a moist filter paper on the bottom. Cover it and incubate on a hot plate $\left(60^{\circ} \mathrm{C}\right)$ for 1 hour. "Cold" method is preferable when the material is poor or valuable, whereas "hot" method is faster, but there is a risk of detachment the albumen layer.

5. Development, fixation and mounting slides. After impregnation (if the "hot" method used, let the dishes to cool at room temperature) remove the protargol solution, leaving a layer of fluid of about $1-3 \mathrm{~mm}$ above the smear. Controlling under a stereomicroscope, add dropwise a developer solution. It is recommended to use modified Foley's developer (Foley 1943, Dieckmann 1995) that less wrinkle the protein layer, although the developing time can take up to 5 minutes or more. A good indicator of the sufficient staining is the colour of macronuclei which becomes reddish-brown. Remove the developer and rinse fast two times in distilled water. Using a micropipette, apply a very small drop of $0.2 \%$ solution of gold chloride. The drop should not be more than sufficient to cover the smear. The cells will decrease in size and become dark grey. After about $0.5-1$ minutes rinse and add $2.5 \%$ oxalic acid solution for $1-2$ minutes until the ciliates change their colour from dark grey to blue-violet or reddish-purple. NOTE. The use of gold chloride is not necessary, but it makes the impregnation picture more contrast and deep. It also stops a development and helps to smooth and strengthen the smear. Taking into account that gold chloride is used in negligible amounts, this does not affect significantly the cost of the technique. If not using gold chloride, the addition of oxalic acid solution is also desirable for breaking development and smoothing the albumen film. Such step is known in classical photography as a "stop bath".

Remove the acid solution and wash for at least 2 times for 3 minutes. Note that the smear should be completely washed out from the acid residues to prevent the appearance of an undesirable sulphur precipitate during the following fixation. Add $2.5 \%$ sodium thiosulfate solution for 0.5-1 minutes. Wash at least three times for 3-5 min. and transfer coverslip to a hot plate $\left(60^{\circ} \mathrm{C}\right)$ until the smear is dried (usually $2-3 \mathrm{~min}$.). After drying, if desired, the smear can be circled by Indian ink using a micropipette and again placed on a hot plate for drying the ink stroke. Place a small ( $2 \mathrm{~mm}$ ) drop of Canada balsam or another medium on the smear and the same one to a slide. Gently lower the coverslip on the slide joining the droplets.

Photomicrographs of impregnated species of ciliates from different habitats are shown in Fig. 1-4.

\section{DISCUSSION}

The proposed technique only at first glance seems complicated. In fact, up to 10 coverslips can be handled at the same time by optimizing the sequence of washing and treatment with reagents. Some "classical" steps have been modified in the protocol. Hardening of albumen layer in strong alcohol with further rehydration is replaced by fixing in alcohol-formol (Tuffrau 1967, Silva-Neto 2000) that saves time. Replacing the processing of the slides in the series of alcohols and xylene before mounting by simply drying does not affect the quality of slides, but reduces the harmful effects of hazardous volatile reagents. Even large specimens (see Figs 4AC) are only slightly deformed. Indeed, after mounting cells into the albumen-glycerol layer, coverslips are being dried, as in the other protocols (Dieckmann 1995, Foissner 2014), so the treatment in alcohol and xylene seems superfluous, especially since the fixation in the alcohol-formol makes the cells more rigid (see step 2). At all stages, the washing time is shortened, which also speeds up the procedure without losing quality.

The use of coverslips and small Petri dishes makes each step easy to control under a stereomicroscope. In the case of unforeseen circumstances (detachment of the albumen film or peeling of some large specimens), it allows saving material, which is sometimes scarce, but very valuable in quantitative studies. The use of chemicals is reduced, thereby improving the workplace safety and reducing the cost of the method.

The main advantage of the proposed method is the use of synthesized protargol in situ. The high cost of commercial silver proteinate for microscopy and instability of the results prompted us to search for alternatives. Initially, more or less good results were obtained by activating inexpensive silver proteinate preparations for medical use: $1 \%$ silver nitrate solution was saturated with strong $(25 \%)$ ammonia solution to dissolve the precipitate formed, and then was mixed with an equal volume of $2 \%$ protargol solution that is available in pharmacies as an antiseptic agent. This solution, diluted before (1:3), works as "true" protargol for microscopy, but may be used only once and has short shelf life, yielding large volumes of silver waste.

In the recently published method of "an in-house protocol" of protargol synthesis, the authors have proposed to obtain a powdery product as an alternative to commercial reagents that are bad or not working (Pan et al. 2013). This method is based on the previous 

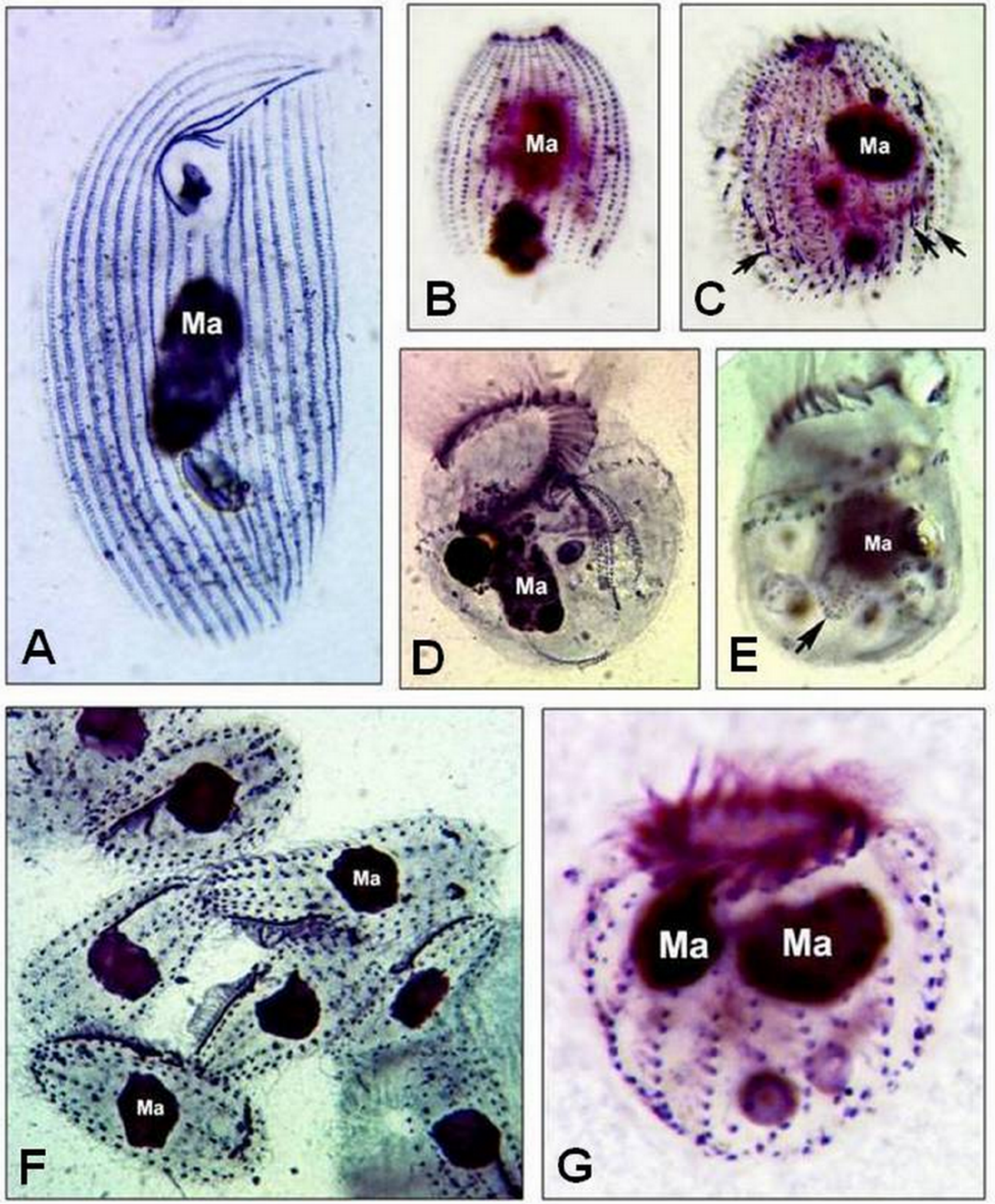

Figs 1A-G. Overview of the slides stained with in situ synthesized protargol. A - Trithigmostoma cucullulus Jankowski, 1967 (Danube, fouling); B - Urotricha sp. 1 (Danube, plankton); C - Urotricha sp. 2 (Black Sea, plankton), arrows point to the extrusomes; D, E - Strombidium sp. (Black Sea, psammon), arrow in $\mathbf{E}$ shows the ingested ciliate that also stained; $\mathbf{F}$ - Pseudocohnilembus pusillus (Quennerstedt, 1869) Foissner \& Wilbert, 1981 (Black Sea, psammon under seaweeds wracks); G - Strombidinopsis minima (Gruber, 1884) Lynn, Montagnes, Dale, Gilron \& Strom, 1991 (Black Sea, seaweeds-associated community). Ma (hereinafter) - macronucleus. 
114 A. V. Kurilov
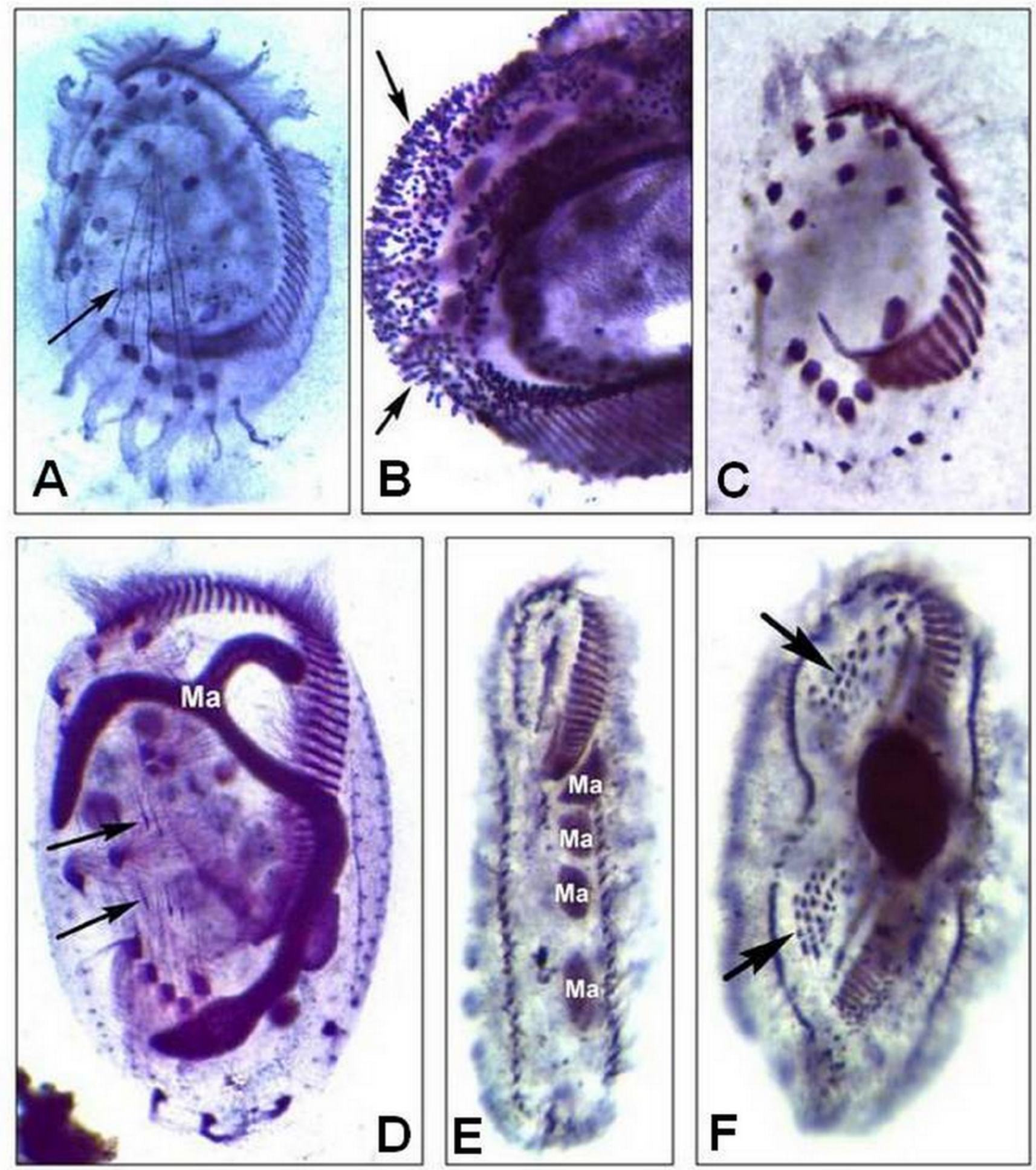

Figs 2A-F. Overview of the slides stained with in situ synthesized protargol. A - Euplotes mutabilis Tuffrau, 1960 (Black Sea, interstitial), arrow shows microtubules; B - Diophrys scutum (Dujardin, 1841) Kahl, 1932 (Black Sea, psammon), arrows point to the rod-like bacterial (?) epibionts; C - Euplotes balteatus Kahl, 1932 (Black Sea, plankton); D - Euplotes woodruffi (Gaw, 1939) Borror \& Hill, 1995 (Danube, plankton), arrows show the microtubular structures; E, F - Holosticha sp. (Kuyal'nitskiy liman), arrows in F indicate the anlage of frontoventral cirri. 

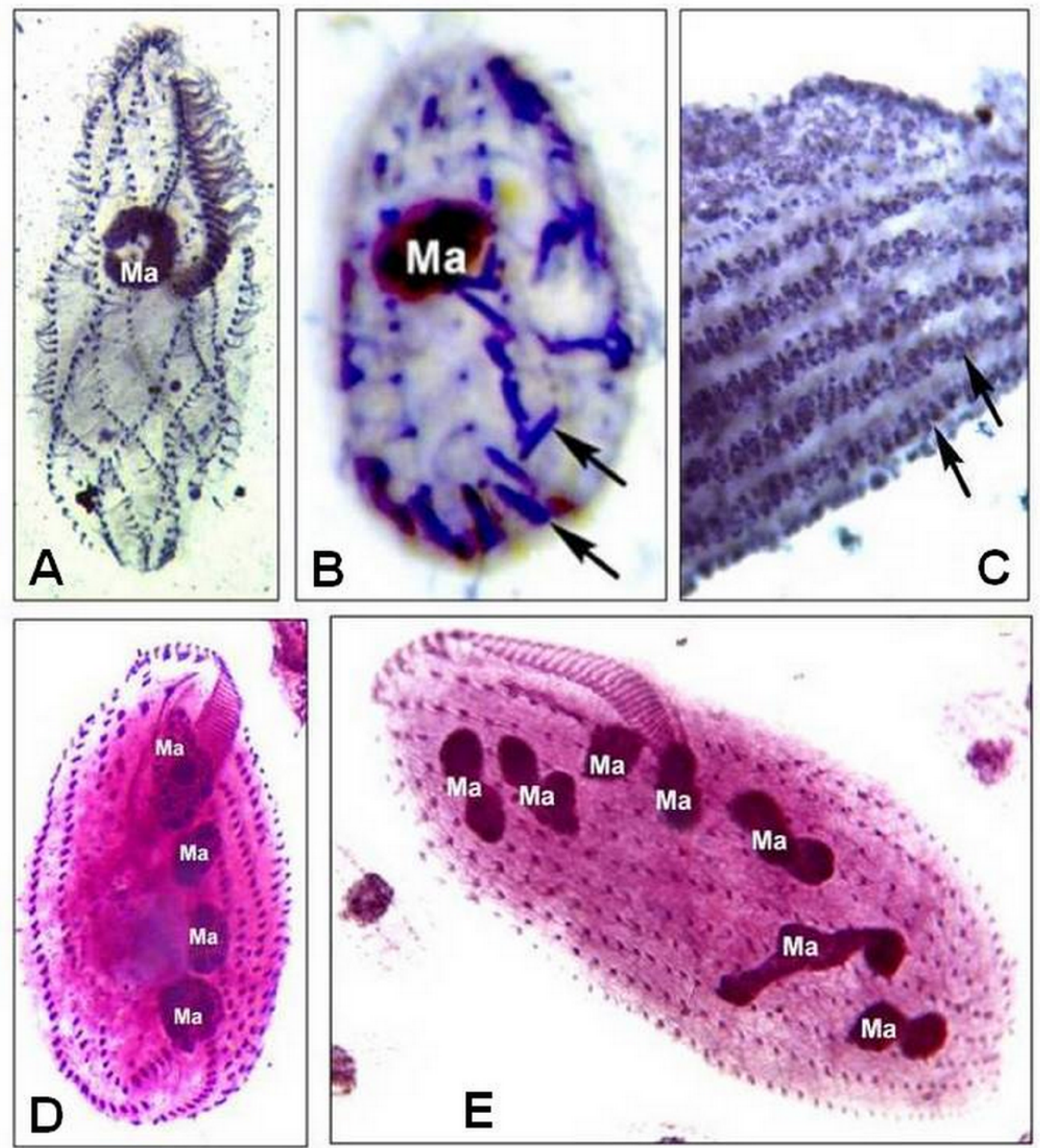

Figs 3A-E. Overview of the slides stained with in situ synthesized protargol. A, B - unidentified ciliates from Kuyal'nitskiy liman, arrows in B point to the rod-like bacterial (?) epibionts; C - Tracheloraphis sp. (Black Sea, psammon), arrows show the cortical granules; D - Metaurostylopsis marina (Kahl, 1932) Song, Petz \& Warren, 2001; E - Pseudokahliella marina (Foissner et al., 1982) Hu \& Song, 2003. 
116 A. V. Kurilov
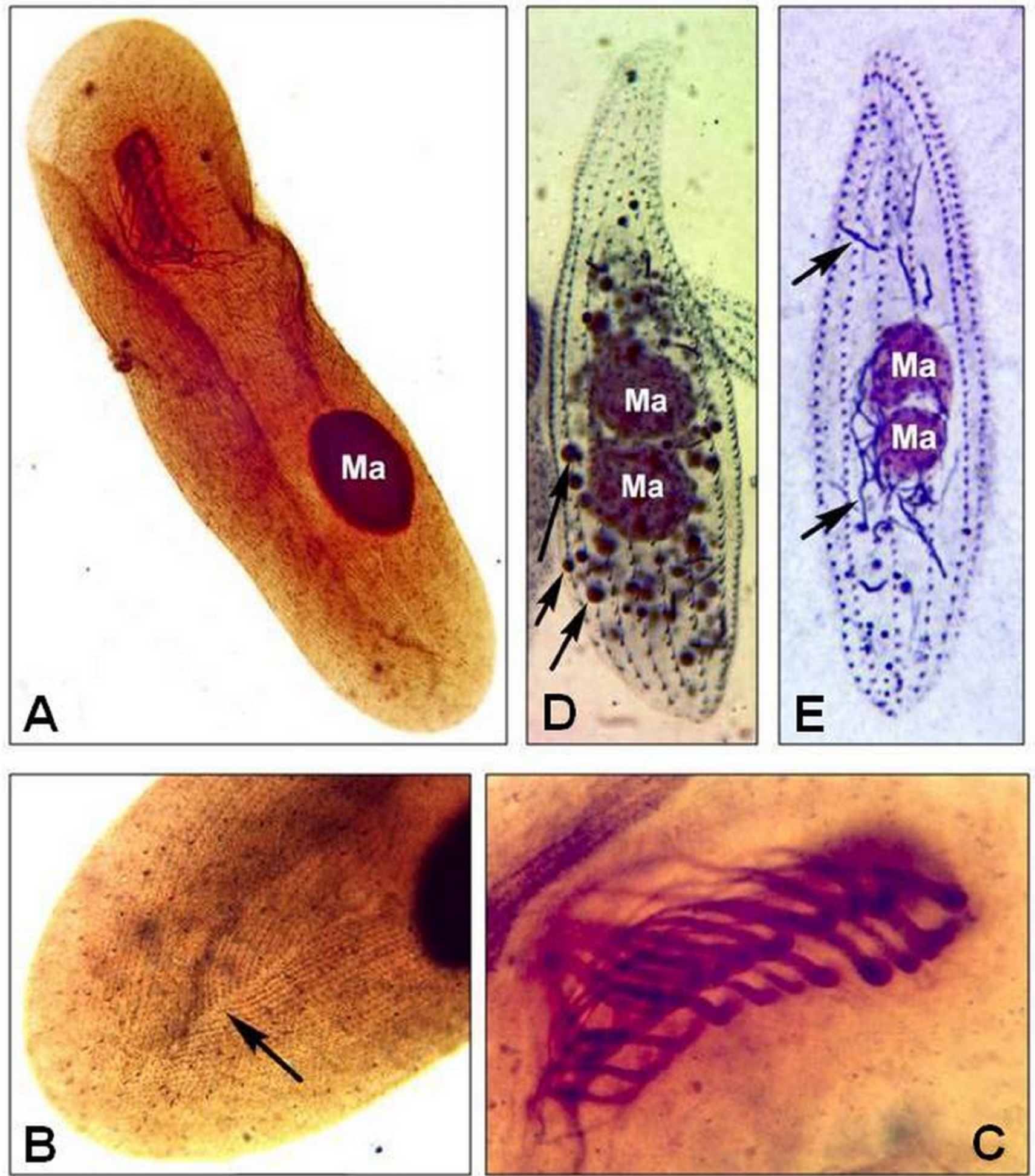

Figs 4A-E. Overview of the slides stained with in situ synthesized protargol. A, B and C - Paraclathrostoma gigas Dragesco, 1996: A - general view, arrow in B shows the ventral post suture, C - peribuccal nematodesms; D - Litonotus fusidens (Kahl, 1926) Foissner et al., 1995; E - Litonotus lamella Schewiakoff, 1896 
experience of researchers for staining of nervous tissue and provides good results for ciliates. However, synthesis of such powdered protargol is time-consuming $(48 \mathrm{~h})$, laborious and requires special laboratory conditions as well as hazardous chemicals (acetone, ammonia). Also, this method yields little amounts of the final product, but produces large amounts of silver waste. In addition, not all grades of the peptone are suitable. Thus, direct synthesis of protargol immediately before use (i.e. in situ) in the form of a ready-to-use solution may be considered as a simple alternative.

In the present work, the idea of such synthesis was also taken from the staining method of nervous tissues (Peters 1958), as the author suggested stability of the results provided by a solution of silver proteinate synthesized directly from protein-containing substances and silver nitrate in alkaline medium. In contrast to the one, proposed by Peters, the formula was changed by replacing the egg protein or casein with more available peptone and using sodium hydroxide instead of the alkaline borate buffer. The concentration of ingredients was adjusted in order to obtain a solution corresponding approximately to $1 \%$ solution of commercial protargol containing about $8 \%$ silver in dry weight (as usually announced by the manufacturers). Three different grades of peptone of various expiry dates and from different producers, as well as a dry commercial preparation of serum from human blood, have been tested with equal success.

Thus, it can be expected that a wide range of commercially available protein products may be suitable for the proposed method.

Acknowledgements. I want to express my deep gratitude to two anonymous reviewers for the meticulous study of the manuscript and valuable critical remarks. Also, I would like to thank Mrs. Galina Hollands (UK) and Mr. Vladimir Vasilenko (Canada) for improving the English draft.

\section{REFERENCES}

Borror A. C., Hill B. F. (1995) The order Euplotida (Ciliophora): Taxonomy, with division of Euplotes into several genera. J. Eukaryot. Microbiol. 42: 457-466

Dieckmann J. (1995) An improved protargol impregnation for ciliates yielding reproducible results. Europ. J. Protistol. 31: 372 382

Dragesco J. (1996) Infraciliature et morphométrie de cinq espèces de ciliés mésopsammiques méditerranéens. Cah. Biol. Mar. 37: 261-293

Fernandez-Galiano D. (1976) Silver impregnation of ciliated protozoa: procedure yielding good results with the pyridinated silver carbonate method. Trans. Am. Microsc. Soc. 95: 557-560
Fernandez-Galiano D. (1994) The ammoniacal silver carbonate method as a general procedure in the study of protozoa from sewage (and other) waters. Wat. Res. 28: 495-495

Foissner W. (2014) An update of 'basic light and scanning electron microscopic methods for taxonomic studies of ciliated protozoa'. Int. J. System. Evol. Microbiol. 64: 271-292

Foissner W., Berger H., Blatterer H., Kohmann F. (1995) Taxonomische und ökologische Revision der Ciliaten des Saprobiensystems. Band IV: Gymnostomatea, Loxodes, Suctoria. - Informationsberichte des Bayerischen Landesamtes für Wasserwirtschaft, 1/95: 1-540

Foissner W., Wilbert N. (1981) A comparative study of the infraciliature and silverline system of the fresh-water scuticociliates Pseudocohnilembus putrinus (Kahl, 1928) nov. comb., P. pusillus (Quennerstedt, 1869) nov. comb., and the marine form P. marinus Thompson, 1966. J. Protozool. 28: 291-297

Foley J. O. (1943) A protargol method for staining nerve fibers in frozen or celloidin sections. Stain Techn. 18: 27-33

$\mathrm{Hu}$ X., Song W. (2003) Redescription of the morphology and divisional morphogenesis of the marine hypotrich Pseudokahliella marina (Foissner et al., 1982) from scallop-culture water of North China. J. Nat. Hist. 37: 2033-2043

Jankowski A.V. (1967) A systematic of the genus Chilodonella and the proposed new genus Trithigmostoma gen. n. Zool. J. 46: 1247-1250 (In Russian with English summary)

Kahl A. (1930-1935) Urtiere oder Protozoa. I: Wimpertiere oder Ciliata (Infusoria), eine Bearbeitung der freilebenden und ectocommensalen Infusorien der Erde, unter Ausschluss der marinen Tintinnidae. In F. Dahl (Ed.), Die Tierwelt eutschlands (Pt. 18 (year 1930), 21 (1931), 25 (1932), 30 (1935)). Jena: G. Fischer: 1-886

Klein B. M. (1958) The "dry" silver method and its proper uses. J. Protozool. 5: 99-103

Lynn D. (1992) Protargol staining. In: Protocols in protozoology (Eds. J. J. Lee and A. T. Soldo). Society of Protozoologists, Allen Press Inc.: C4.1-4.8

Lynn D. H., Montagnes D. J. S., Dale T., Gilron G. L., Strom S. L. (1991) A reassessment of the genus Strombidinopsis (Ciliophora, Choreotrichida) with descriptions of four new planktonic species and remarks on its taxonomy and phylogeny. J. Mar. Biol. Ass. U.K. 71: 597-612

Ma H., Choi J. K., Song W. (2003) An improved silver carbonate impregnation for marine ciliated protozoa. Acta Protozool. 42: 161-164

Montagnes D. J. S., Lynn D. H. (1987) A Quatitative Protargol Stain (QPS) for ciliates: method description and test of its quantitative nature. Marine Microb. Food Webs 2: 83-93

Pan X., Bourland W. A., Song W. (2013) Protargol Synthesis: An In-House Protocol. J. Eukaryot. Microbiol. 60: 609-614

Peters A. (1958) Staining of nervous tissue by protein-silver mixtures. Stain Techn. 33: 47-53

Petz W. (1999) Ciliophora. In: South Atlantic Zooplankton I, (Ed. Demetrio Boltovskoy). Backhuys Publishers, Leiden: 265-319

Schewiakoff W. T. (1886) Organization and Systematic of Infusoria Aspirotricha (Holotricha auctorum) // Proc. Imperial Acad. Sc. St. Petersburg, 4: 1-395 (In Russian)

Silva-Neto I. D. da (2000) Improvement of silver impregnation technique (protargol) to obtain morphological features of protists ciliates, flagellates and opalinates Rev. Brasil. Biol. 60: $451-459$ 
Skibbe O. (1994) An improved quantitative protargol stain for ciliates and other planktonic protists. Arch. Hydrobiol. 130: 339347

Song W., Petz W., Warren A. (2001) Morphology and morphogenesis of the poorly-known marine urostylid ciliate, Metaurostylopsis marina (Kahl, 1932) nov. gen., nov. comb. (Protozoa, Ciliophora, Hypotrichida). Europ. J. Protistol. 37: 63-76

Tuffrau M. (1960) Révision du genre Euplotes, fondée sur la comparaison des structures superficielles. Hydrobiologia 15: 1-77

Tuffrau M. (1967) Perfectionements et pratique de la techinique d'impregnatiom au protargol des infusoires cilies. Protistologica 3: 369-399
Wicklow B. J., Hill B. F. (1992) A short procedure for protargol staining In: Protocols in protozoology (Eds. J. J. Lee and A. T. Soldo). Society of Protozoologists, Allen Press Inc.: C5.15.4

Received on $17^{\text {th }}$ May, 2017; revised on $5^{\text {th }}$ September, 2017; accepted on $7^{\text {th }}$ September, 2017 